\title{
CONSTRUÇÕES COM O VERBO PASSAR: MUDANÇA CONSTRUCIONAL EM PERSPECTIVA FUNCIONAL
}

Geisa Maria Jayme Jordão (UFF)

Resumo: Este artigo apresenta os resultados obtidos em nossa tese, sob a perspectiva da linguística funcional, que investigou as construções formadas com o verbo passar pleno, aquele que seleciona argumentos, ex: "... eu passei na roleta do ônibus..." (D\&G) e sua migração para passar auxiliar, aquele que acompanha um verbo pleno, constituindo as construções perifrásticas que marcam aspecto inceptivo, ex: "Como o caso foi levado à Corte, passei a coletar todo tipo de cone..." (RG). Com o intuito de investigar as relações sintático-semânticas das construções com passar, foram determinados quatro subesquemas de análise, sendo três para as construções com passar pleno, nos quais analisamos 314 construções, e um subesquema para as construções perifrásticas com passar auxiliar, em um total de 80 casos. Assim nossos corpora totalizam 394 construções com passar. Visando a uma análise diacrônica, pesquisamos textos dos séculos XVIII, XIX, XX e XXI, nas seguintes fontes: Corpus Discurso e Gramática (D\&G), Corpora do Projeto Para a História do Português Brasileiro (PHPB), Corpus do Português (CP), Programa Roda Viva (RV) e Revista O Globo (RG). Os corpora foram constituídos por registros da oralidade (D\&G) e escritos (PHPB, CP, RG, RV), nos gêneros: entrevistas, cartas e artigos, todos apresentando sequências narrativas. Os dados foram analisados, a partir de grupos de fatores correspondentes aos subesquemas sintáticosemânticos, com o objetivo de acompanhar o pareamento forma $\leftarrow \rightarrow$ função das construções com passar.

Palavras-chave: Funcionalismo; Verbo passar; Construções; Mudança linguística.

Abstract: This article presents the results obtained in our theses, under the perspective of functional linguistic, that investigated the constructions formed with the verb to pass full, the one that selects arguments, i.e: "...I passed the roulette wheel on the bus..." (D\&G) and its migration to verb to pass auxiliary, the one that accompanies a full verb, forming periphrastic constructions that mark inceptive 
aspect, i.e: "- As the case was taken to Court, I started to collect ("passei a coletar") every type of cone..." (RG). With the intention of investigating the syntactic-semantic relations of constructions with to pass, four subesquemes were determined for analyses, being three for constructions with to pass full, in which we analysed 314 constructions, and one subsqueme for periphrastic constructions with to pass auxiliary, in a total of 80 cases. So our corpora had 394 constructions with to pass. Aiming for a diachronic analyses, we researched texts from the centuries XVIII, XIX, XX and XXI, from the sources: Corpus Discurso e Gramática (D\&G), Corpora do Projeto Para a História do Português Brasileiro (PHPB), Corpus do Português (CP), TV Show Roda Viva (RV) e Magazine $\mathrm{O}$ Globo (RG). The corpora were constituted by registries of orality (D\&G) and writing (PHPB, CP, RG, RV), in the genres: interviews, letters and articles, all presenting narrative sequences. The data was analyzed from groups of factors in relation to the syntactic-semantics subesquemes, with the objective of accompanying the pairing form $\leftarrow \rightarrow$ function of constructions with to pass.

Keywords: Functionalism; Verb to pass; Constructions; Linguistic change.

\section{INTRODUÇÃO}

Para o desenvolvimento desse artigo, apresentamos partes de nossa tese que investigou o deslizamento do verbo passar pleno a verbo auxiliar de construções inceptivas. Ressaltamos que nosso objetivo é mostrar os resultados obtidos nas análises das construções com o verbo passar. Foi estabelecido, por base teórica, o funcionalismo linguístico, pautado nas pesquisas de Bybee (2007, 2008, 2010, 2015, 2016), Traugott (1993, 2008), Traugott \& Trousdale (2013), Trousdale (2014), Heine (1991, 1993, 2002), Heine \& Kuteva (2007, 2008), Hopper (1991, 2001), Halliday (1994), entre 
outros, e algumas contribuições da linguística cognitiva, principalmente com foco nas obras de Goldberg (1995, 2003, 2006), Fillmore (1968) e Croft (2001). Entre os pesquisadores brasileiros, aplicamos os estudos de Travaglia (2002, 2003, 2006, 2007, 2010), Castilho (1968, 2002, 2014, 2015), Borba (1990, 1996) e Cançado (2005).

As análises foram feitas em um total de 394 dados de construções com o verbo passar. Desses dados, 314 correspondem a passar pleno e 80 correspondem a passar auxiliar em construções perifrásticas. O verbo passar realizase, tradicionalmente, como verbo de movimento, pode apresentar variadas predicações e selecionar diferentes argumentos. Estabeleceu-se, como critério metodológico, para a organização e análise dos dados, quatro subesquemas, sendo três subesquemas para as construções com passar pleno: subesquema I - para as construções com movimentação física do sujeito: "... eu passo pra cozinha... aí eu olho..."; subesquema II - para a movimentação não física do sujeito: “... aí ela ficou quieta... ficou sem ação... foi e passou o relógio..."; e subesquema III - para o movimento de extensão: “... aí passa um creme pra amaciar o pelo..."; e um subesquema para as construções com passar auxiliar: “... e desse dia... eu passei a pensar mais na minha vida..." (dados do D\&G). Esses subesquemas estão interligados pelo esquema semântico geral 
de movimento: Origem > Percurso > Meta. Para acompanharmos o deslizamento de verbo pleno para verbo auxiliar, seguimos o esquema: Movimento > Tempo > Auxiliar.

Para que pudéssemos obter resultados satisfatórios, estabelecemos as seguintes hipóteses: (1) o verbo passar pleno mantém seu status de verbo de movimento em todos os usos pesquisados; (2) o seu uso mais prototípico deu origem ao seu uso como verbo auxiliar; (3) o verbo passar auxiliar apresenta valor inceptivo, equivalendo-se aos verbos inceptivos canônicos começar, iniciar e principiar; (4) a preposição a forma com o verbo passar auxiliar uma construção aspectual inceptiva.

Com a finalidade de responder às hipóteses levantadas, destacamos os principais objetivos estabelecidos: pesquisar os trabalhos que envolvem o verbo em estudo, já à disposição na literatura; (2) levantar em dados de fala e de registro formal o uso e a frequência do verbo em construções com passar pleno e passar auxiliar; (3) estabelecer subesquemas de análise; (4) encontrar um espaço na gradiência de usos que tenha propiciado o preenchimento do verbo passar como auxiliar inceptivo.

\section{PRESSUPOSTOS TEÓRICOS}

As abordagens centradas no uso, como o funcionalismo, veem a sintaxe como uma estrutura que está a serviço do discurso. 
Portanto, no campo da sintaxe, os funcionalistas consideram mais aceitável a ideia da não-arbitrariedade. Neste aspecto, o posicionamento funcionalista consiste em dar relevo aos usos sociais, passando a compreendê-los como nível gerador da gramática das línguas. Dentre os princípios e as categorias centrais do funcionalismo estão: informatividade, iconicidade, marcação, transitividade e gramaticalização. Destacamos, para acompanhar nossa análise, os princípios da gramaticalização. Heine (2002) mostrou que o desenvolvimento diacrônico de itens gramaticais pode ser descrito por meio de um roteiro de estágios sucessivos, associados a diferentes tipos de contextos. Nesse sentido, Heine estabelece que, do significado fonte (mais concreto ou menos abstrato) para o significado alvo (mais abstrato), estão envolvidos três tipos de contextos ${ }^{1}$ : contexto bridging, contexto de mudança e convencionalização. Heine (2002) argumenta que o processo de gramaticalização envolve quatro estágios contextuais, correspondentes a um continuum de mudança:

1) Estágio inicial: nesse estágio o contexto é natural, são expressões com significado fonte ou normal, podendo ocorrer em variados contextos.

2) Contexto ponte: também chamado de contexto de transição. Nesse estágio, um contexto específico dá origem

1 Contexto aqui é entendido como estágios de gramaticalização. 
a uma inferência, aparecendo outro significado - chamado alvo - que apresenta uma interpretação mais plausível do enunciado em questão. Nesse contexto há ambiguidade pragmática e semântica.

3) Contexto de mudança: há um novo tipo de contexto que não permite mais de uma interpretação em termos de significado fonte. O novo contexto é incompatível com o significado fonte. Nesse estágio ocorre a mudança, a gramaticalização.

4) Convencionalização: nesse estágio, o significado alvo está aberto a uma maior manipulação, já que é livre de restrições contextuais que deram origem a ele. Pode ser usado em novos contextos.

Os contextos de Heine (2002) guardam correlação com os contextos de Diewald (2006), conforme ilustra o quadro abaixo:

\begin{tabular}{|l|c|c|}
\hline \multicolumn{1}{|c|}{ Estágio } & Contexto & Significado/função \\
\hline $\begin{array}{l}\text { I pré-condições de } \\
\text { gramaticalização }\end{array}$ & atípico & $\begin{array}{c}\text { implicaturas } \\
\text { conversacionais }\end{array}$ \\
\hline $\begin{array}{l}\text { II gatilho para a } \\
\text { gramaticalização }\end{array}$ & crítico & opacidade múltipla \\
\hline $\begin{array}{l}\text { III reorganização e } \\
\text { diferenciação }\end{array}$ & de isolamento & polissêmico/hererossêmico \\
\hline
\end{tabular}

Quadro 1: Tipos de contextos em gramaticalização (Fonte: Diewald (2006).2)

Os contextos de Heine e de Diewald guardam similaridades entre eles. Rosário e Oliveira (2016, p.238) destacam que os autores "concebem contexto como cline".

2 Novas reflexões foram apresentadas em proposta recente de Diewald \& Elena Smirnova (2012, p.111-134), ampliando os tipos de contextos em gramaticalização. 
Os ambientes normais ${ }^{3}$ tornam-se ambíguos e passam a ser reinterpretados, em seguida, para além da reinterpretação semântico-pragmática, ocorrem neoanálises ${ }^{4}$, configurando a fase de mudança e por último a convencionalização, conforme Heine (2002), ou contexto de isolamento, segundo Diewald (2006). Na Gramaticalização, sob uma perspectiva centrada no uso, a gramática é um organismo maleável e sensível a mudanças. Para Traugott (2014), “Gramaticalização é o desenvolvimento de expressões procedurais, entre elas as expressões de tempo, aspecto, modalidade, caso, pronomes pessoais, complementizadores e outros conectivos". A autora cita como exemplo prototípico de gramaticalização o desenvolvimento de BE going to. "Inicialmente um verbo de movimento usado em uma construção teleológica imperfectiva, passou a ser usado como um auxiliar. Aqui há perda de significado de movimento e de intenção".

\section{CONSTRUÇÃO - UMA ABORDAGEM CENTRADA NO USO}

Para Bybee (2010), construções são padrões efetivos de uso, formas mais concretas de expressão e não virtualidades. Construções têm representação exemplar, uma vez que dependem do seu nível de esquematicidade. As investigações de padrões de uso linguístico, no funcionalismo, junto a uma

3 Os ambientes contextuais normais referem-se a modos de expressão convencionalizados em uma comunidade linguística.

4 Traugott e Trousdale preferem o termo neoanálise à reanálise. 
abordagem construcional, no campo das pesquisas cognitivas, conferem mais precisão aos estudos desenvolvidos neste viés. Considera-se nesta interface a maior ligação entre função e forma. Verifica-se a importância nesse campo da concepção construcional às pesquisas que envolvem a mudança gramatical e as relações contextuais presentes.

Segundo Bybee (2008), a frequência de uso leva ao enfraquecimento semântico. As mudanças fonológicas de redução e fusão das construções em gramaticização 5 são condicionadas pela alta frequência e pelo uso em porções de fala contendo informação dada ou velha. A perda semântica permite o uso do elemento linguístico em novas associações pragmáticas, o que leva a uma mudança semântica da construção. A autonomia de um item muito frequente causa o entrincheiramento desse item na língua. Bybee propõe type frequency (frequência de ocorrência de uma unidade, geralmente uma palavra ou morfema, em texto corrido) e token frequency (frequência de dicionário de um determinado padrão).

Das contribuições cognitivistas, uma das mais relevantes para o funcionalismo tem sido a proposta de pareamento forma x sentido defendida por Croft (2001, p.18), concebida da seguinte forma:

5 Gramaticização - termo utilizado por alguns teóricos com sentido semelhante à gramaticalização. 


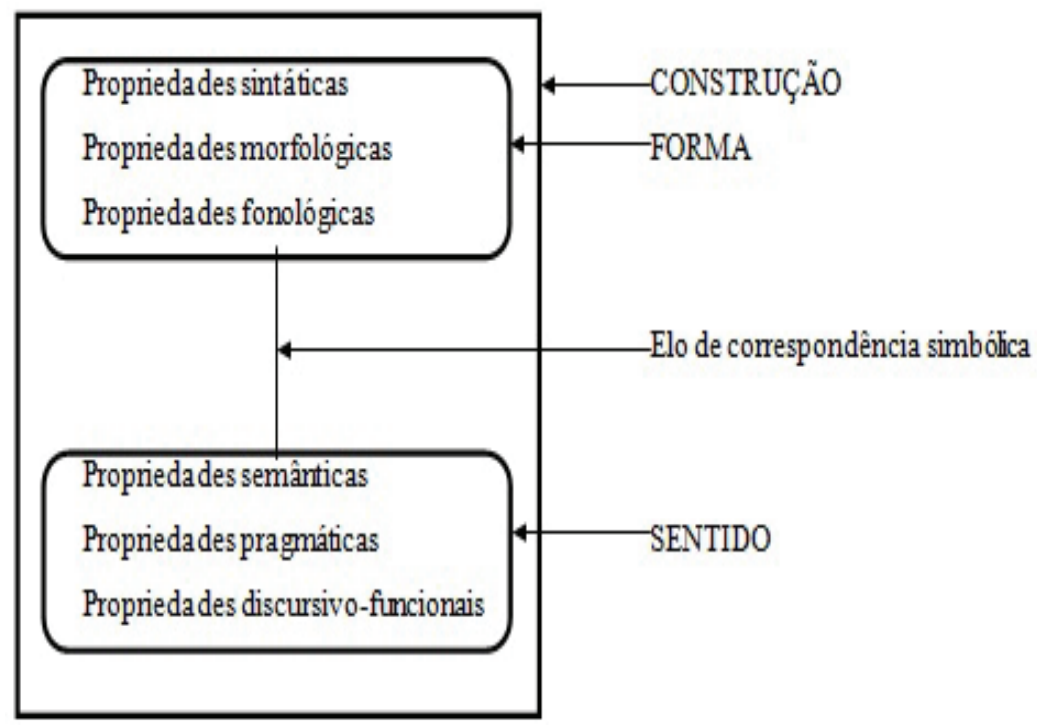

Quadro 2: Proposta de Croft (2001)

Verifica-se que o elo entre a forma e o sentido convencional é interno à construção, logo, estruturas conceptuais podem ser universais, entretanto, cada língua tem sua especificidade. O termo SENTIDO alcança todos os aspectos convencionalizados da função da construção. Para o estudo das etapas de gramaticalização, em perspectiva diacrônica, é necessário levar em conta os seis fatores correlacionados, ou seja, o uso contextualizado.

A partir dos tokens das microconstruções [(X) Vpassar (Y)] estabelecemos os seguintes fatores de análise, correspondentes aos subesquemas, a partir do Esquema: Origem $(\mathrm{O})>$ Percurso $(\mathrm{P})>$ Meta $(\mathrm{M})$ para as construções 
com passar lexical e o Esquema [(SN) V1 + a +V2], para passar auxiliar. Com base em Croft (2001), a minha proposta é:

\section{Quanto à forma:}

a. Propriedades Sintáticas: -Posição do verbo passar pleno e auxiliar;

-Perda de propriedades sintáticas: passar pleno;

- Expansão sintática: construções perifrásticas.

b. Propriedades Morfológicas: - Perda de traços de verbo pleno; passar auxiliar; -Formação de uma só categoria gramatical.

c. Propriedades Fonológicas: -Formação de grupo de força.

Quadro 3: Proposta com base em Croft (2001)

\section{Quanto ao sentido:}

a. Propriedades Semânticas:

- Abstratização do sentido original;

- Transitivida de do verbo passar;

- Aspecto verbal.

b. Propriedades Pragmáticas: -Analogia e Meta forização;

-Mudança funcional.

c. Proprieda des Discursivo-funcionais: - As sequências narrativas;

-Os gêneros: entrevistas, cartas, artigos.

Quadro 4: Proposta com base em Croft (2001)

\section{MUDANÇA CONSTRUCIONAL}

Traugott (2011c) e Traugott \& Trousdale (2013) buscam um refinamento dos pressupostos da abordagem construcionista da gramaticalização e apresentam uma diferenciação entre o que seria mudança construcional e, em sentido mais estrito, o 
processo denominado "construcionalização". De acordo com Traugott (2011c), a mudança construcional afetaria somente os subcomponentes das construções já existentes, sejam eles relacionados ao significado: subcomponentes de natureza semântica, pragmática e discursiva; ou subcomponentes ligados à forma: subcomponentes de natureza fonética, morfológica e sintática, conforme os postulados de Croft (2001). Para Traugott (2012), mudanças construcionais podem preceder ou acompanhar construcionalização.

A construcionalização é um subtipo de mudança construcional em que formanova - sentidonovo de signos são criados através de uma sequência de pequenos passos e neoanálises de forma e significado. A construcionalização deve ser interpretada não só como processo de mudança, mas também como resultado da própria mudança.

Traugott e Trousdale (2013) estabelecem que o estudo das construções de uma língua pode ser feito a partir de uma hierarquia que considera três níveis: esquemas, subesquemas e microconstruções. O construto representa a frequência token, o locus da mudança. Para Traugott e Trousdale (2013), a abordagem construcional da mudança linguística parte do princípio de que a língua - tanto no que se refere à gramática quanto ao léxico - é formada por redes taxonômicas de construções, as quais se organizam de modo hierárquico. 
Para Trousdale (2014), o fenômeno da construcionalização deve ser tratado como distinto da mudança construcional, que afeta as características de nós existentes na rede linguística, pois não cria novos nós. Os signos criados como resultado de construcionalização devem ser localizados em um continuum desde procedurais até de conteúdo e vice-versa. Isso significa que muitas construções são intermediárias, até certo ponto. Trousdale (2014) destaca que esquema é uma construção complexa, com slots abertos, enquanto esquematicidade de uma construção é o grau em que uma construção é fonologicamente subespecificada e semanticamente geral. Quando novas construções gramaticais (caso de passar) se desenvolvem, pode haver tanto mudanças que afetam esquemas, com o surgimento de um novo subesquema, quanto mudanças que afetam a esquematicidade de uma microconstrução, por exemplo, quando um significado codificado se torna mais abstrato. Semelhante à esquematicidade, também a produtividade é um fenômeno gradiente. À medida que novas microconstruções gramaticais passam a existir, elas se esparramam gradualmente, aumentando sua frequência de uso.

\section{O VERBO PASSAR}

Entre inúmeras informações de dicionários sobre o verbo passar, trazemos as definições do Dicionário Gramatical de Verbos do Português Contemporâneo do Brasil (BORBA, 1990 p.978-984): 
Indica ação-processo. 1. Com sujeito agente/causativo e com dois complementos: um expresso por nome concreto e outro locativo. 2. Com sujeito agente expresso por nome humano. (O número 2 é expandido em 2.1 até 2.15). 3. Com sujeito agente expresso por nome animado e com dois complementos: um expresso por nome designativo de lapso de tempo. II. Indica processo. 1. Na forma pronominal e 1.1. Com sujeito paciente expresso por nome designativo de fenômeno da natureza e com locativo. (O número 1 é expandido até 1.18). 2. A forma pronominal ou não, com sujeito paciente expresso por nome designativo de tempo, significa decorrer, transcorrer. 3. Na forma pronominal, com sujeito paciente expresso por nome designativo de evento, significa acontecer, produzir-se. III. Indica ação. 1. Com sujeito agente expresso por nome animado. 1.1. Com complemento de percurso, apagável, significa deslocarse em movimento contínuo. (é expandido até 1.4). 2. Com sujeito agente expresso por nome humano. 2.1. Com dois complementos: um da forma de + nome designativo de lugar e outro da forma a/para + nome designativo de lugar, significa mudar, saltar. (2.1 é ampliado até 2.15). IV. Indica estado. 1. Com sujeito inativo expresso por nome designativo de filme, peça de teatro ou programa de televisão e com locativo, apagável, significa ter apresentação de exibição. 2. Na forma 
pronominal ou não, com sujeito inativo expresso por nome. (2.1 é ampliado até 2.4). 3. Com sujeito inativo expresso por nome animado. 3.1. Com complemento da forma sem + nome ou oração infinitiva, significa viver. (3.1 é ampliado até 3.2.) 4. Com sujeito inativo expresso por nome não-animado e com complemento da forma de + nome ou adjetivo ou ainda sem sujeito e com complemento da forma de + nome indicativo de hora, significa exceder, ir além. V. É auxiliar precedido de a + infinitivo para indicar aspecto inceptivo. VI. É verbalizador. 1. Passar vistoria. 2. Passar calote. 3. Passar repreensão. 4. Passar descompostura. VII. Expressões.

Em nossa análise, as preposições que formam as construções com passar apresentaram resultados significativos, confirmando a semântica de movimento desse verbo, ligado a preposições que marcam Origem - Percurso - Meta. Também destacamos a presença da preposição a formadora da construção aspectual inceptiva. Exemplos de ocorrências registradas por maior frequência nos corpora.

a. "por" - preposição do eixo horizontal, encaixada no ponto medial. Seu sentido base é indicar trajeto, o que vem a compor com o verbo de movimento físico ou fictício, uma unidade. Seu uso apresenta caráter polissêmico, pois convergiram para esse item as preposições latinas pro e per. Pro indica o papel temático de beneficiário, enquanto per indica "através de", "por meio de". 
(01) - O Neymar é o primeiro que vem à cabeça. O fato de ter alisado o cabelo encoraja outros homens a mudar a textura dos fios. É um jogador que passou por uma transformação, que ficou mais bonito, mais fashion - observa Tiago Parente. (RG 08.06.2014, p.86).

b. "em" - preposição que faz parte do eixo horizontal e indica ponto final do percurso: meta. Conforme Castilho (2014, p.598), a preposição em também indica a localização de um evento. "... coocorre um verbo de movimento (ou um verbo suporte) cujo sujeito é controlador do evento" (CASTILHO, 2014, p.598).

(02) "Anselmo se formou em Direito em 2012. Assim que passar no exame da Ordem dos Advogados do Brasil (OAB), pretende fechar o quiosque e mudar de profissão." (RG-02.11.2014, p.28).

c. "de" - igualmente às anteriores, faz parte das preposições do eixo horizontal e indica o ponto inicial de um percurso ou origem. A figura é disposta numa localização inicial verbalizada pelo ponto de referência. "O movimento assim balizado pode ser real, quando se dá no Espaço ou no Tempo reais, deslocando-se o participante de um ponto de origem para um ponto de destino" (CASTILHO, 2014, p.597).

(03) "comigo? bem... constrangedora... engraçada... tá... constrangedora (riso) na praia... saí com... com um pessoal... be/ ba/ foi/ foram há muitos anos... eu era... até pequena... aqui no Leblon... e ... foi... foi numa época que as ondas... eram em/ estavam enor::mês... né? então o pessoal passou da arrebentação... foi lá pro fundo... e::/ ah... eu... eu fiquei lá ((estalo de dedos)) o máximo que eu pude depois eu comecei a me cansar... né? eu estava ficando cansada e tal "ah... gente... eu vou voltar..." o pessoal "Ah:: não ... tá.." e ficaram por lá... eu voltei..." (D\&G - RJ - Inf 7) 
d. "para" - Preposição que marca o ponto final do percurso: a meta. Em nossos corpora, em relação ao passar pleno, as preposições para, a e em entram em variação sintática quando acompanham verbos de movimento. O uso de para é mais frequente do que o uso de a em construções com passar pleno.

(04) I: é... e:: assim... eu... mais... juntamente com... uma e... uma equipezinha daqui da escola mesmo... dos estudantes... se reúne... eh::... pega as fofocas... os recados que está... rolando aí com o pessoal da escola... pega homenagem também para os professores... e coloca pensamentos... coloca/ eh... uma pregada de coisa dentro do... dentro de jornalzinho... de duas folhas... aí a gente digita... aqui no/ na escola mesmo... depois passa pros alunos... E: e como/ é... é digitado na escola... né? I: ahn... ahn... E: vocês digitam no computador? I: no computador... E: e as pessoas... os alunos... compram muito esse jornal? (D\&G - Nit - Inf. 2)

e. "a" - Nos registros de passar pleno, essa preposição apresenta uso reduzido, competindo com para.

(05) “O apresentador do Roda Viva, Mario Sergio Conti, mal deu boa noite aos telespectadores no início do programa da segunda-feira, 6, e já passou a palavra ao entrevistado".

Segundo Neves (2000, p. 603), "a preposição a funciona no sistema de transitividade, isto é, introduz complemento". Ao introduzir complemento de verbo, este se refere a um ponto de chegada ou a um ponto final de referência (meta). A autora destaca que a preposição a entra na construção de perífrases verbais (+infinitivo): "Em pouco tempo esse diminutivo genérico passaria a indicar especialmente o tipo de canção importada do Brasil (PHM)" (p.623). 
Para Wiedemer (2014, p. 115), após evidenciar a sistematicidade dos usos das preposições em sua pesquisa com os verbos de movimento: caminhar, chegar, entrar, ir, levar, mudar, partir, sair e voltar, esclarece: "primeiramente, para representar as relações espaciais, as preposições mobilizam as categorias cognitivas de regiões espaciais, que resultam dos seus sentidos bases":

a) Preposição a/para: categoria cognitiva contato, que implica a ideia de "em direção a x";

b) Preposição por: "passar por x";

c) Preposição em: "estar em x";

d) Preposição de: "vem de x".

Para Wiedemer (2014), as preposições possuem um sentido prototípico de base, e os demais sentidos são derivados dos processos pragmáticos. Avaliando seus resultados, o autor encontrou, além dos significados previstos, isto é, prototípicos de algumas preposições, o desenvolvimento de significados mais abstratos, os quais denominou de "inespecífico". Isso ocorre com a preposição para,

que pressupõe na sua significação um ponto de referência "meta", passa a admitir outros tipos de complementos locativos mais abstratos, ou seja, quanto maior o processo de desbotamento semântico, maior o seu grau de gramaticalização, e, por consequência, 
seu significado passa a depender mais do contexto pragmático. (WIEDEMER, 2014, p.116)

O estudo de Travaglia (2010, p.109) revelou que a gramaticalização das construções com os verbos começar / passar-continuar - acabar / terminar e deixar apresentaram valores aspectuais, mas os mesmos se gramaticalizam para exercer também outros valores gramaticais, estes se mostraram de três naturezas distintas como:

a) Marcadores de categorias: verbos que marcam e que expressam alguma categoria gramatical do verbo (tempo, voz, modalidade, aspecto) ou de outra classe. Incluindo nesse caso os verbos auxiliares.

b) Indicadores: verbos que expressam noções semânticas muito gerais e mais abstratas que não constituem situações tais como repetição, cessamento, resultado, entre outros.

c) Funcionais: verbos que exercem funções textualdiscursivas, como: marcadores conversacionais, ordenadores argumentativos, modalizadores, entre outros. Os verbos que passaram dessa classe lexical para classes mais gramaticais da língua (como conectores/conectivos, preposições, advérbios, por exemplo) etc. "Incluir-se-iam nesta última categoria os verbos de ligação por sua função relacional de conector ou conectivo" (TRAVAGLIA, 2010, p.110). 
Em nossos corpora, encontramos o verbo passar e o verbo começar apresentando construções perifrásticas em competição, isto é, como auxiliar, o verbo passar funciona com valor de verbo que marca início de uma situação, semelhante ao verbo começar.

(06) "eu vou contar uma história que eu achei triste... foi uma/ um caso que aconteceu... há uns três anos atrás... foi a minha primeira experiência com relação a namorado... eu conheci uma pessoa... o Alexandre... eh... ele mora na minha rua mesmo... aí/ só que nós nunca tivemos contato... de re... de repente ele começou a frequentar... mais assim... a minha casa e as minhas amizades... ele... na época... ele tinha de/ eh... quase dez anos mais velho do que eu... eu tinha quatorze anos... aí nós come/ eh... nós passamos a conversar num... num dia qualquer... numa sexta-feira à noite... aí ele começou... a me reparar... e eu reparar ele... aí nós ficamos conversando... ele falou que... me admirou muito... ele falou que eu não parecia que eu tinha quatorze anos..." ( D\&G - RJ - Inf.7).

O exemplo acima vem ao encontro dos postulados de Hopper (1991), no sentido de formas em competição, pois observa-se que o falante usa a perífrase aspectual inceptiva com o verbo começar (mais tradicional) e, no decorrer da conversa, vai usar a perífrase com o verbo começar, porém, não termina de pronunciar, substituindo o verbo começar pelo verbo passar, que também marca o início de uma ação, com valor aspectual inceptivo. Na sequência, volta a usar o verbo começar, um caso de motivação em competição. 
Hopper (1991), ao abordar os princípios de gramaticalização, destaca Estratificação (layering) ${ }^{6}$ : dentro de um domínio funcional, novas formas estão constantemente emergindo, mas isto não significa que as formas antigas desaparecem; elas coexistem com as emergentes. Uma palavra passa a ter vários usos, cada uso corresponde a uma camada num domínio funcional. Hopper (1991) entende por domínio funcional algumas áreas gerais como tempo, aspecto, modalidade, caso e referência. Nesse sentido, o verbo passar emerge como verbo auxiliar.

\section{ANÁLISE DOS DADOS}

Trabalhamos com quatro subesquemas de análise, sendo três para passar pleno e um para passar auxiliar. Nosso objetivo foi agrupar os casos semelhantes, levando em consideração a frequência de usos mais concretos para usos mais abstratos. Nosso olhar observa o subesquema sob dois pontos: (i) semântico e (ii) sintático. A seguir apresentamos nossos subesquemas, acompanhados de alguns dados e de quadros com os resultados das análises.

\begin{tabular}{|cccc|}
\hline $\begin{array}{c}\text { Agente } \\
\mathrm{S}\end{array}$ & Vpassar & Percurso/Meta & Nível semântico \\
$\mathrm{V}$ & (Oblíquo/OI) & Nível sintático \\
\hline
\end{tabular}

Quadro 5: Subesquema 1

6 Princípio também conhecido por camadas: quando dois ou mais itens ou construções da língua podem competir num mesmo campo semântico em momentos variados de sua trajetória, segundo alternativas funcionais ou estilísticas à disposição dos usuários. 
O primeiro subesquema vai priorizar o verbo passar em construções que apresentam o deslocamento físico do sujeito, focalizando a meta ou percurso. A construção que se segue traz o verbo formando um bloco semântico com seu complemento através de uma preposição. A análise desse subesquema contempla o movimento com deslocamento físico do sujeito:

(07) "O fotógrafo de guerra André Liohn foi o convidado desta segunda-feira (30/4) do Roda Viva. O brasileiro saiu de Botucatu - SP para ficar frente a frente ao calor da batalha. Hoje é um fotógrafo especialista em coberturas de guerra. Já passou pela Somália, Síria, Haiti e Líbia._(RV)

O exemplo acima demonstra a relevância da preposição por marcando o deslocamento físico do sujeito. As construções desse subesquema são mais concretas. A preposição por, localizada no ponto medial do eixo horizontal, tem sentido de percurso.

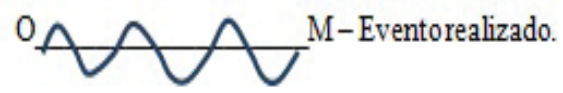

\begin{tabular}{|ccc|}
\hline agente & Vpassar & Paciente(Semântico)Significado \\
S & V & OD $\quad$ (Sintático)Forma \\
\hline
\end{tabular}

Quadro 6: Subesquema 2

Esse subesquema vai tratar do movimento do sujeito gramatical ou do sujeito falante, sem deslocamento físico. 
A valência verbal tem foco no deslocamento do objeto, que tem papel temático paciente, e também na permanência temporal.

(08) "Eu espero todas as alunas chegarem, mando colocar os chinelos no canto da sala e inicio a aula. Começo com deslocamento e elas vão caminhando pela sala depois eu mando elas se espalharem e início o alongamento que é uma série de exercícios para aquecer depois que elas estão aquecidas eu passo as coreografias_que são preparadas no final de cada aula." (D\&G - Nit - Inf.13).

De acordo com Cunha e César (2011), no português, os verbos de movimento são subcategorizados por Sprep que indica origem, caminho e/ou meta, mas também podem ser acompanhados por SN objeto que codifica o participante que se move. Conclui-se, então, que todos os verbos de movimento têm um participante, seja uma pessoa ou uma coisa, que se move, codificado sintaticamente como sujeito ou objeto direto. Embora mais distantes do protótipo, os verbos de movimento acompanhados de OD não podem ser excluídos numa abordagem que prevê um tratamento escalar da transitividade.

\section{Subesquema 3}

A atividade do Sujeito leva o objeto a se modificar ou a se deslocar até um recipiente ou contêiner, apresentando valor incoativo. Este valor representa a movimentação do objeto em direção a um recipiente. Só nesse esquema foi considerada a ideia de contêiner. 
Padrão: Agente Vpassar Objeto afetado > (S Prep)/recipiente/contêiner $\mathrm{S} \quad \mathrm{VT} O \quad>\mathrm{R} / \mathrm{C}$

Quadro 7: Subesquema 3

Esse grupo se assemelha ao 20 no que tange aos Sgramatical e/ou Sfalante que não sofrem deslocamento, mas difere por apresentar atividade do sujeito que promove o movimento do objeto, isto é, este se desloca em direção a um contêiner.

Nesse grupo, ocorrem Sfalante/Sgramatical [+animado] [+agentivo] e Objeto [+paciente] [-animado]. O verbo passar apresenta acepção de atividade dos Sfalante/Sgramatical com modificação do objeto, que vai sofrer alterações físicas. Essa mudança de estado, segundo Lakoff \& Johnson (2002) ocorre em função de eventos e ações serem metaforicamente conceptualizados como objetos, atividades como substâncias, estados como recipientes. Destacamos o exemplo abaixo por considerá-lo prototípico, em relação ao recipiente ser [humano] compartilhando o papel temático de [beneficiário]:

(09) “...pega homenagem também para os professores... e coloca pensamentos... coloca/ eh... uma pregada de coisa dentro do... dentro de jornalzinho... de duas folhas... aí a gente digita... aqui no/ na escola mesmo ... depois passa pros alunos..." (D\&G - Nit - Inf.2).

O gráfico que se segue demonstra as preposições associadas a passar pleno ao longo dos séculos. 
Consideramos fundamental o levantamento das preposições por elas formarem construções mais frequentes nos corpora. Observa-se que a preposição por teve uma queda no século $X X$ e uma ascensão no século XXI. A preposição em cresceu em uso em todos os séculos, diferentemente da preposição de, que, após crescimento no século $X X$, caiu no século $\mathrm{XXI}$. A preposição com presente no século XVIII entra em declínio até o século XXI, como ocorreu com a preposição sem. A preposição a com uso representativo no século XVIII e XIX tem uma queda com passar pleno no século XX e uma pequena subida no século XXI. A preposição para teve seu ápice no século XX e declínio no século XXI.

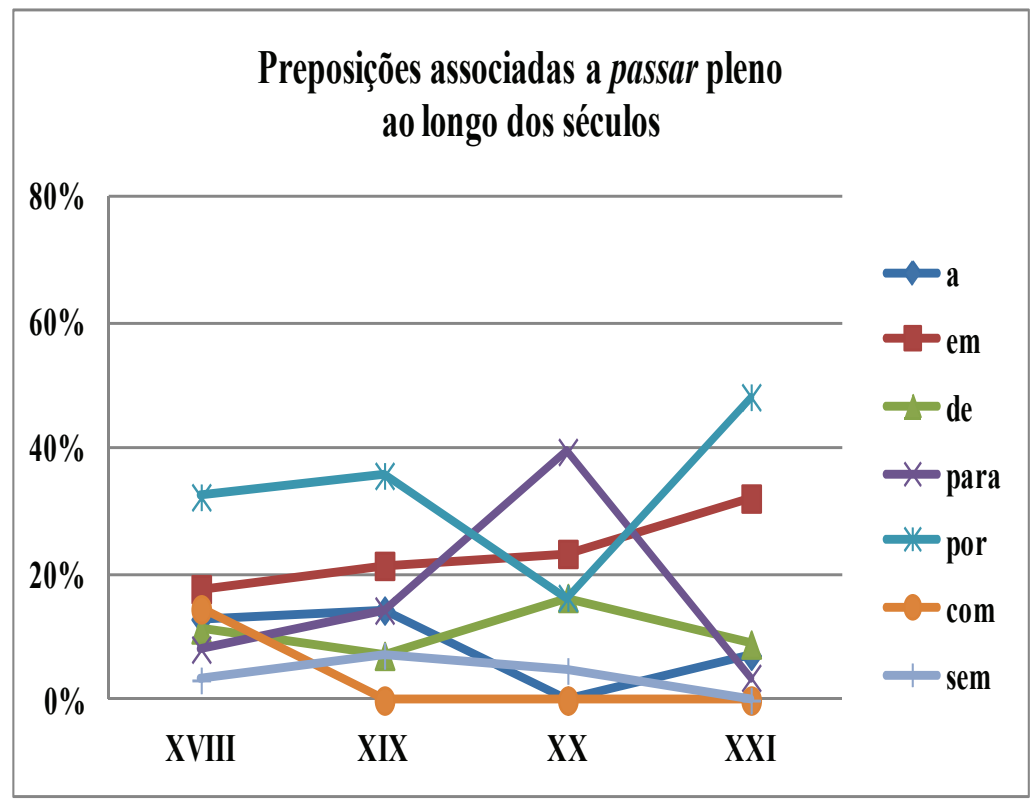

Gráfico 1: Preposições associadas a passar pleno ao longo dos séculos. 
São 175 ocorrências de construções com passar pleno com preposição. A preposição por aparece em todos os corpora e é mais significativa no corpus Roda Viva e na Revista O Globo, ambos do século XXI. No corpus D\&G há destaque para a preposição para. A preposição a aparece com mais expressão no corpus PHPB e no Corpus do Português, marcando os séculos XIX e XVIII. A preposição em é mais expressiva na Revista $O$ Globo e equilibrada nos outros corpora. Com só aparece no CP e sem no CP e no PHPB. Os resultados mostram que o oblíquo indicando percurso no espaço ou no tempo é mais frequente, haja vista a preposição por se destacar das demais.

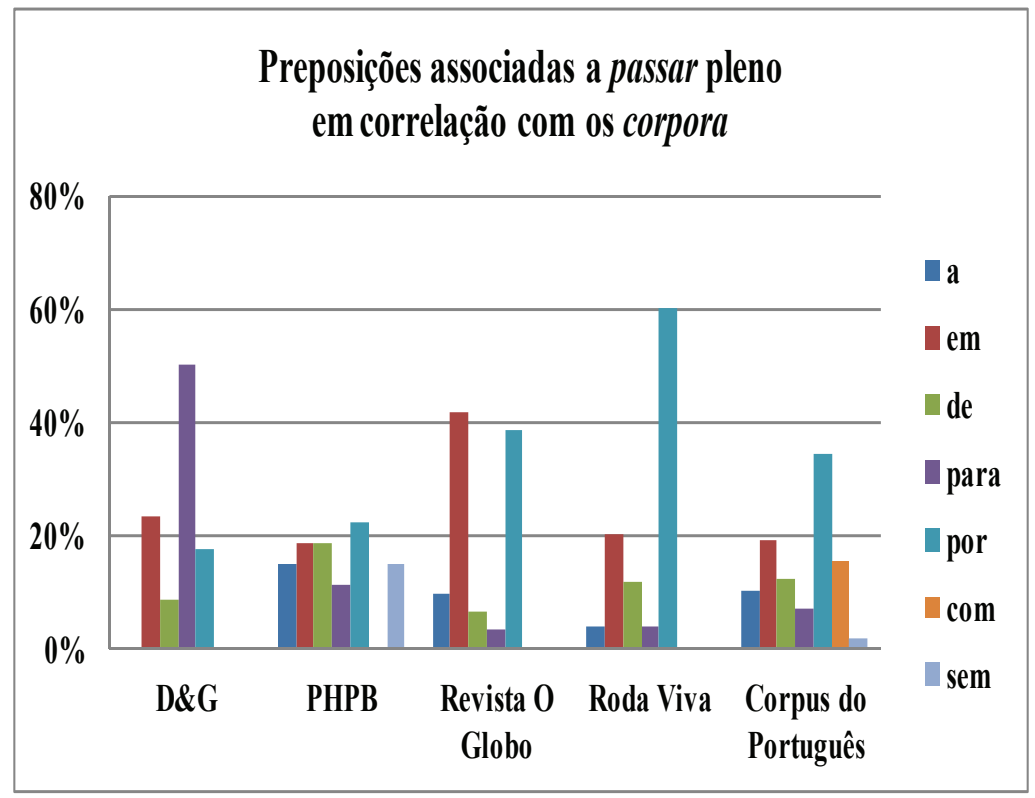

Gráfico 2: Preposições associadas a passar pleno em correlação com os corpora. 
Na sequência das análises, apresentamos no gráfico 3 o movimento do sujeito em correlação com os corpora analisados. Em todos os corpora analisados, há registro de construções que apresentam deslocamento, sendo que na Revista O Globo e no corpus Roda Viva há maior frequência desse movimento. No Corpus do Português (CP) e no PHPB há mais ocorrências de movimento sem deslocamento físico, o mesmo ocorrendo no corpus D\&G, no qual há maior incidência; talvez por se tratar de fala espontânea, igualmente, possamos destacar que, por serem cartas particulares ou familiares, o CP e o PHPB apresentam registros mais próximos aos do D\&G. Esses resultados são relevantes para acompanharmos essa abstratização do sujeito, condição para a mudança da construção com passar pleno para passar auxiliar. O movimento não dinâmico ou estático também é expressivo no CP e no PHPB, ambos referentes aos séculos XVIII e XIX respectivamente. 


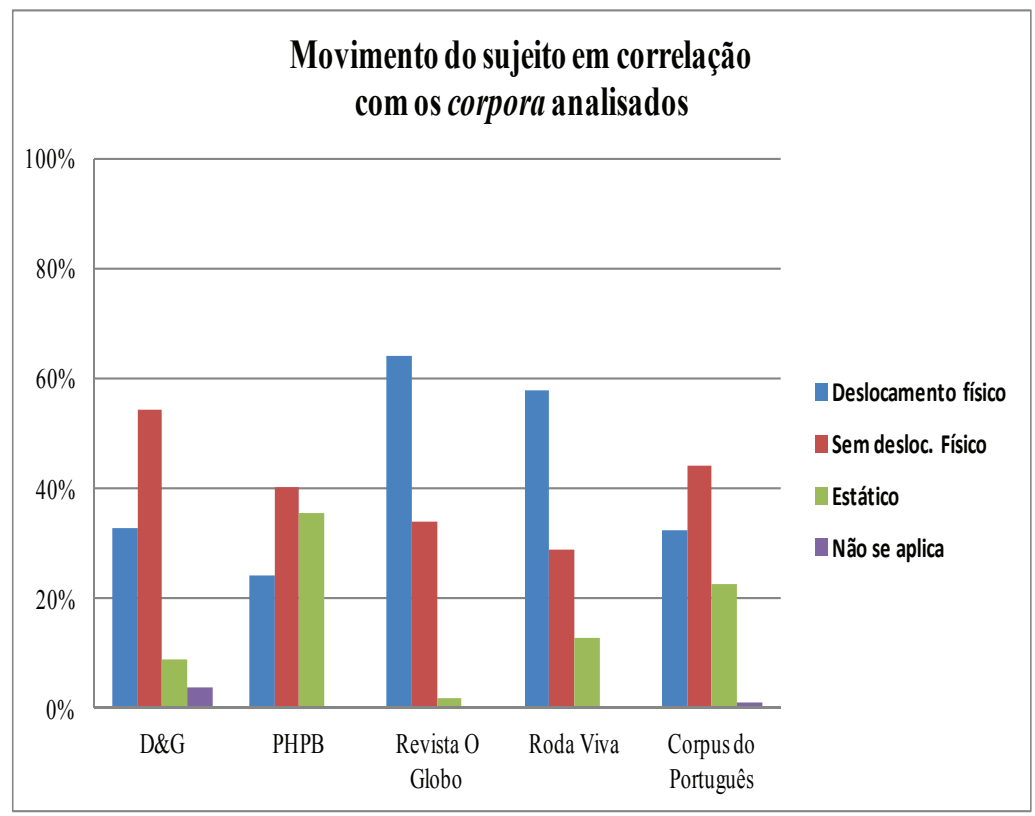

Gráfico 3: Movimento do Sujeito em correlação com os corpora analisados.

A seguir, destacamos o gráfico 4, que registra o movimento do sujeito em correlação com a característica do sujeito sintático. A análise aponta que, para o movimento com deslocamento do sujeito, temos um sujeito [+agentivo][+humano], o destaque também vai para a significativa presença do sujeito [-agentivo] [-humano], como a variação mais promissora de mudança. Esses dados demonstram uma mudança em relação ao movimentodeslocamento. As ocorrências do sujeito experienciador também são relevantes, porque estão muito ligadas ao tipo mental do verbo passar, conforme Halliday (1994). Essas ocorrências são os fortes indícios da mudança linguística de passar, ocorrendo a neoanálise como a base da mudança. 


\begin{tabular}{|l|l|}
\hline Material & 218 casos \\
\hline Mental & 82 casos \\
\hline Relacional & 12 casos \\
\hline Não se aplica & 2 casos \\
\hline Total & 314 casos \\
\hline
\end{tabular}

Tabela 1: Valores semânticos de passar - segundo Halliday (1994)

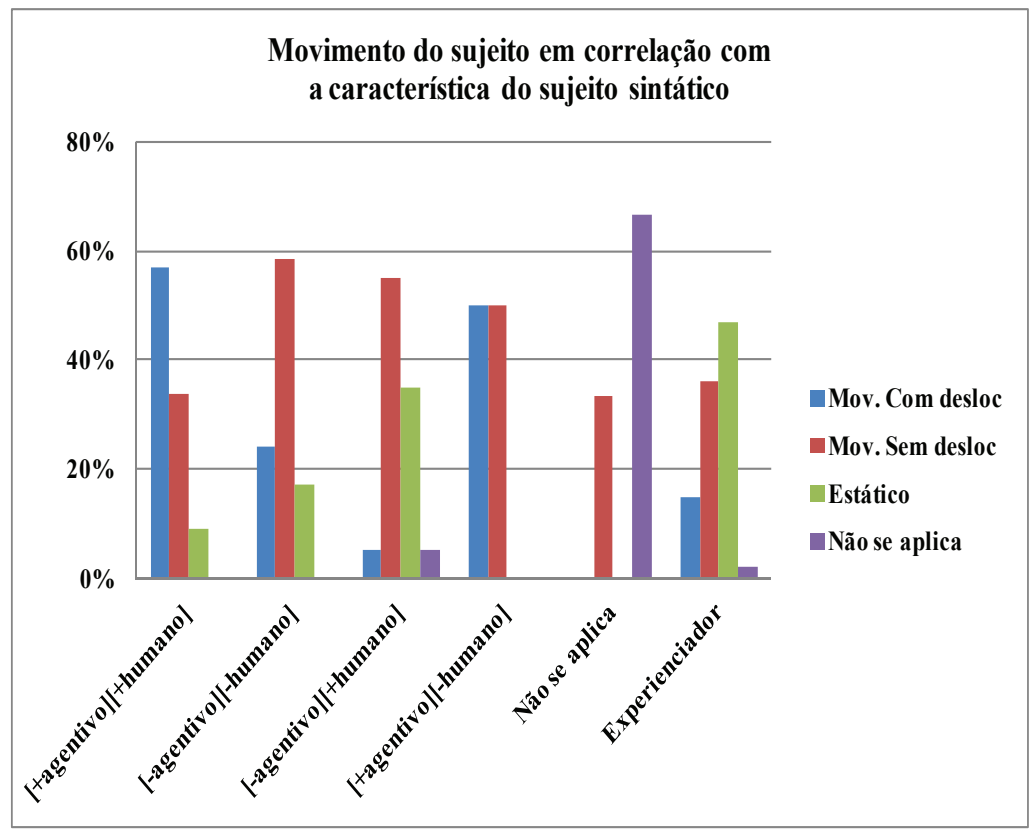

Gráfico 4: Movimento do sujeito em correlação com a característica do sujeito sintático.

$$
\text { [(S) V1fin + ( prep a) + V2inf] }
$$

Quadro 8: Subesquema para a construção de passar auxiliar:

Esse subesquema atende às construções perifrásticas de passar auxiliar. Na formação de uma rede construcional com o verbo passar, será esse o subesquema mais abstrato 
ligado aos subesquemas de passar pleno, formado pelas microconstruções registradas em nossos corpora. O verbo passar apresenta-se como verbo auxiliar, formando perífrase com um verbo pleno no infinitivo e ligado a este pela preposição "a", ou seguido de verbo no gerúndio (alguns poucos casos nos corpora). V2 pode subcategorizar ou não complemento. Vejamos:

(10) "Uma amiga, estava comentando comigo, que ela estava recebendo umas cartas estranhas com declarações de amor, dizendo que observava ela onde estivesse. Então ela passou a ter medo, quase nem saia de casa até que um dia ela descobriu quem mandava as cartas, era um rapaz com a vida meia errada, nisto fez com que ela ficasse mais nervosa." (D\&G - RJ - Inf.2).

Este caso corresponde a uma mudança em relação ao estado anterior do Sgramatical, o verbo passar não perde sua ideia base de movimento, pois existe um movimento no âmbito psicológico, um movimento na linha do tempo. A expansão da metáfora espaço/tempo é uma das fontes de novos significados para as construções em processo de gramaticalização. Uma metáfora mapeia uma relação estrutural de um domínio (normalmente mais concreto) para outro domínio (normalmente mais abstrato) (BYBEE, 2015). A construção apresenta aspecto inceptivo, conforme Castilho (2014). Houve uma mudança em nível psicológico do sujeito. A perífrase "passou a ter" indica que, a partir das cartas, 
surgiu o medo, ideia base do inceptivo, dar início a uma nova situação. A seguir apresentamos os resultados da pesquisa em relação ao sujeito e suas correlações com os corpora utilizados:

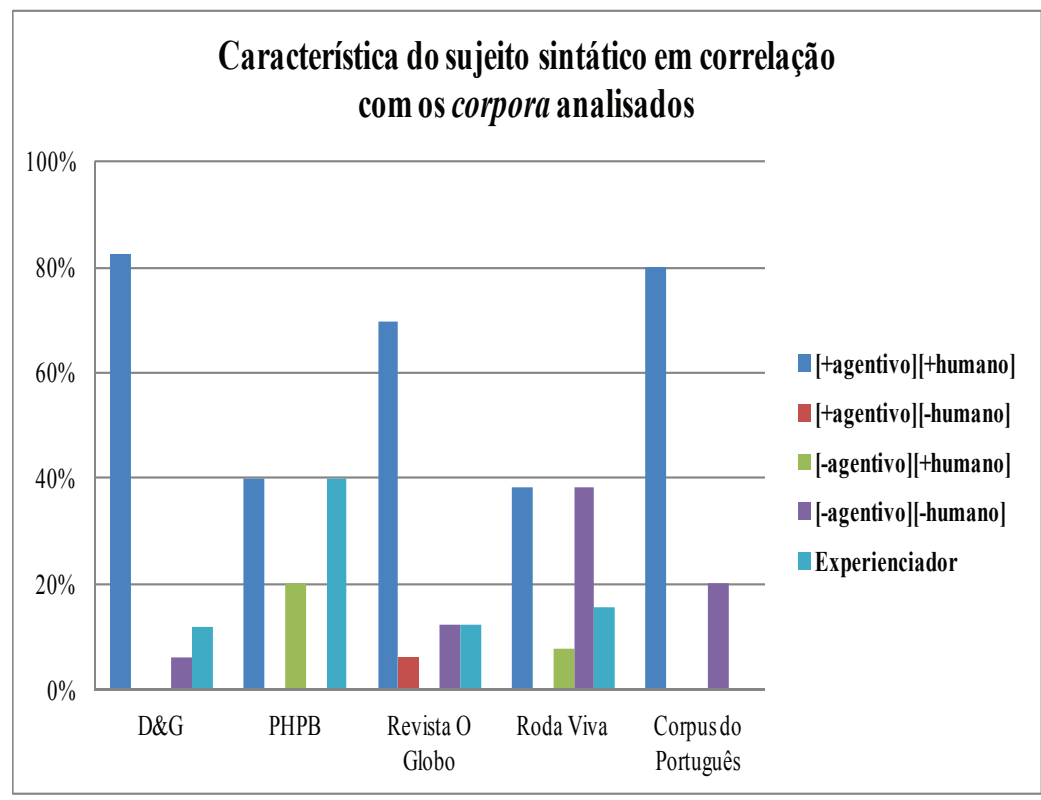

Gráfico 5: Característica do sujeito sintático em correlação com os corpora analisados

Em relação ao sujeito sintático, nossa análise apresenta mais dados para o sujeito [+agentivo] [+humano], em termos quantitativos, mas a análise qualitativa aponta uma mudança significativa em relação ao sujeito, destaque para o sujeito Experienciador e para o sujeito [-agentivo] [-humano] que são mais compatíveis com o verbo passar mais abstratizado, prova da gramaticalização desse verbo e da sua fixação como verbo auxiliar. 
Assim destaca-se que o sujeito Experienciador está mais vinculado à construção $[\mathrm{V} 1+\mathrm{a}+\mathrm{V} 2]$. A reanálise é a alteração de uma classe gramatical, tanto quanto a atribuição de novas funções sintáticas, motivadas pela mudança das fronteiras entre constituintes. Segundo Diewald (2006), o 2ㅇ gatilho para a gramaticalização de construções em relação aos contextos é o contexto crítico marcado por múltiplas situações de opacidade estrutural e semântica. Esse contexto, segundo a autora, o 2을 estágio, desaparece no desenvolvimento posterior, que seria o 30 estágio: contexto de isolamento. Esse estágio trata da organização e diferenciação da nova construção, apresenta a consolidação do processo de gramaticalização em curso. Nesta fase, o novo significado gramatical é isolado como um significado separado do mais antigo, mais lexical, este novo significado não depende mais de uma implicatura conversacional, uma vez que o elemento linguístico em gramaticalização tornouse realmente polissêmico (ARENA, 2015). Como estamos lidando com construções de verbo pleno, que passa a ser usado como auxiliar, destacamos que o convívio entre o 2 o e o 3o estágio pode ficar por muito tempo, conforme Hopper (1991) no princípio Camadas 7 .

Inegável a importância dos contextos, marcando os ambientes propícios de mudança linguística. Em relação

7 Conforme referência 6. 
aos corpora estabelecidos para análise, em todos os séculos e gêneros pesquisados, há a presença da construção perifrástica com passar.

Nossos gráficos comprovam as três características do aspecto inceptivo. (i) O sujeito que predomina na análise é [+agentivo] [+humano]. (ii) As análises demonstram que as construções formadas com passar auxiliar marcam o início de uma situação. (iii) O pretérito perfeito e o presente do indicativo são os tempos mais frequentes nos dados, o que demonstra que essas construções são recorrentes nas estruturas de fundo das narrativas.

\section{RESULTADOS COMPARATIVOS}

Apresentamos a seguir os resultados das construções analisadas com o verbo passar pleno e auxiliar:

PASSAR: PLENO X PERÍFRASE: em correlação com o tipo de sujeito.

O que se depreende do gráfico a seguir é a comparação entre o tipo de sujeito em construções plenas e construções perifrásticas. As construções mais prototípicas estão ligadas ao sujeito [+agentivo] [+humano]. As construções transitivas prototípicas seguem o padrão de sujeito agentivo e objeto paciente afetado pela ação verbal. Nas perífrases ainda é maior a frequência do sujeito [+agentivo] [+humano]. 


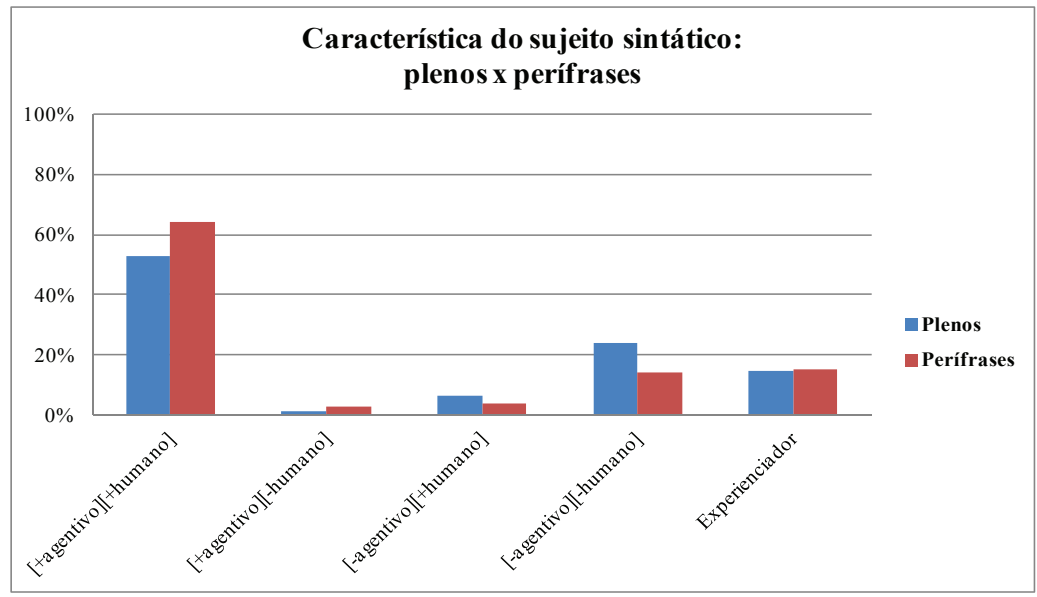

Gráfico 6: Característica do sujeito sintático: plenos x perífrases.

O percentual é muito semelhante para o sujeito [+agentivo] [+humano] nas construções com passar pleno e nas construções com passar auxiliar. Considerando o percentual de 52,5\% de registros em um total de 314 ocorrências para passar pleno e $65 \%$ de casos para passar auxiliar em 80 ocorrências. De acordo com Borba (1996, p. 15), "um predicado preenchido por um elemento que contenha o traço +atividade relacionando-se com um argumento preenchido por um item com o traço +animado vai dar um predicado de ação". Em seguida, observamos o sujeito [-agentivo] [-humano] e o sujeito experienciador já se destacando como uma variação importante nesta abstratização do sujeito, pois é compatível com a abstratização do verbo pleno cooptado a verbo auxiliar. 
A seguir, apresentamos os resultados para os papéis temáticos em correlação com as construções com passar pleno e com passar auxiliar.

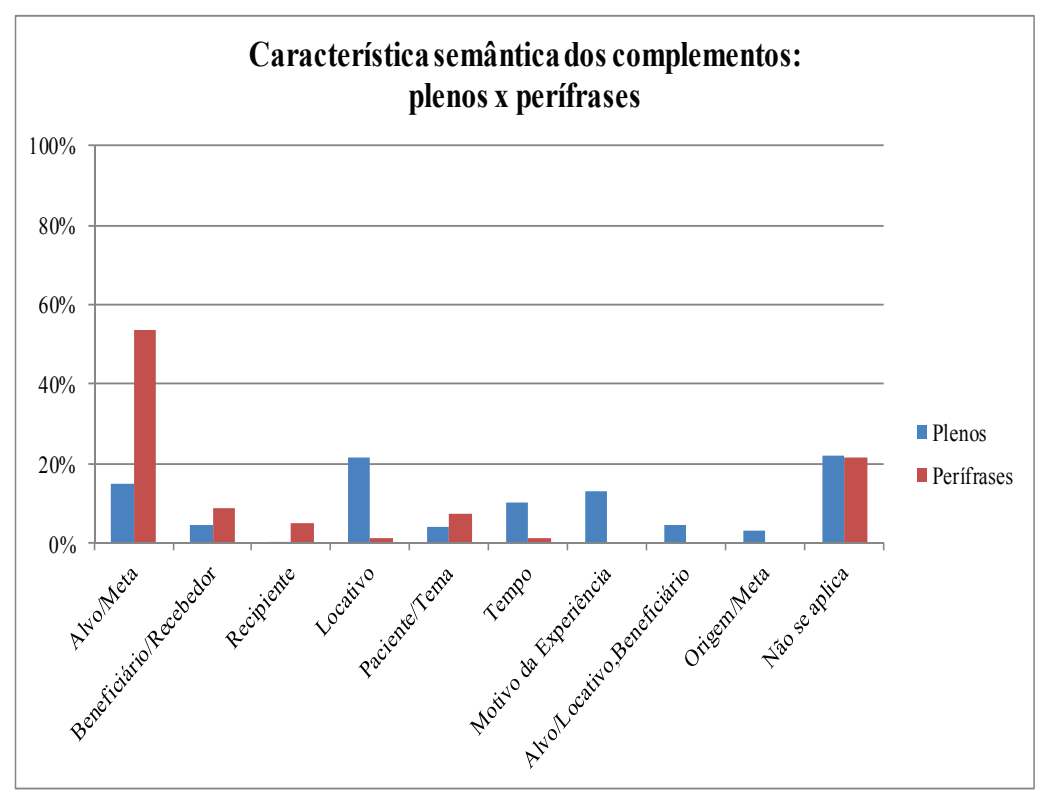

Gráfico 7: Característica semântica dos complementos.

De modo geral, as relações temáticas são estabelecidas entre um verbo e seus argumentos. Comparando os complementos entre as construções com passar pleno e passar auxiliar, verificamos que nas construções perifrásticas há destaque para os papéis Alvo/Meta do verbo principal, papéis compatíveis com propósito. E para as construções com passar pleno o destaque fica por conta do locativo, que, de acordo com Cançado (2008), é o papel que faz 
referência ao lugar em que algo está situado ou acontece, não tem propósito. O fato se explica pelas restrições de seleção semântica entre o verbo e seus argumentos. Como se verifica, o sujeito [+agentivo] [tanimado], no Gráfico 7, está em destaque nas construções de passar pleno, o argumento locativo está coerente, conforme o dado (11), pois o deslocamento físico predomina. Em relação às construções perifrásticas, prevalecem os papéis temáticos Alvo/Meta, papéis representantes da direção para onde o sujeito se movimentou, tanto no sentido literal, como no metafórico (CANÇADO, 2008, p.114). Também prevalecendo um sujeito [+agentivo] [+humano], de acordo com o Gráfico 7, conforme o dado (12).

(11) "[...] quando eu cheguei na escola... tinha um::/ só tinha um lugarzinho lá na frente... eu comecei a sentar naquele lugar... toda vez sentava naquele lugar... aí eu reparava que sempre uma menininha passava lá pra trás quieta... não falava com ninguém... aí um belo dia...quando... quando eu cheguei na sala... meu lugar estava ocupado... tinha um lugarzinho do lado dela... aí eu cheguei...". (D\&G - Nit - Inf.13)

(12) "aí eu... eu fumava... eu bebia... saía de noite... brigava... chegava em casa... brigava com os meus irmãos... agora eu passei a viver nessa outra vida de:: religião... ser crente... como o pessoal fala... ser crente... eu melhorei... graças a Deus... parei de fumar... parei de beber..." (D\&G - RJ2 Inf.74).

A seguir apresentamos os resultados das análises correspondentes às Instanciações de passar ao logo dos séculos: Gráfico 


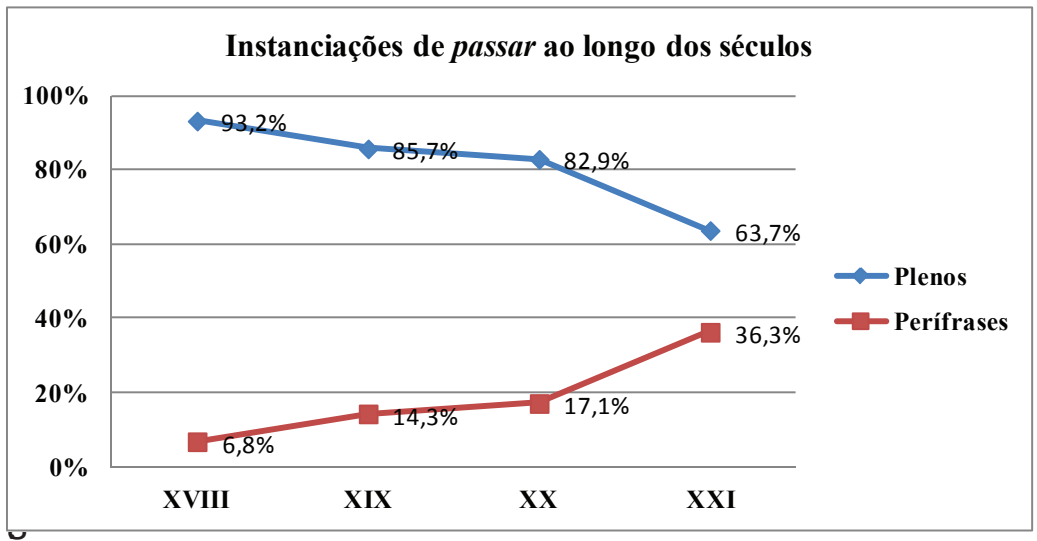

Gráfico 8: Instanciações de passar ao longo dos séculos.

\begin{tabular}{l|c|c|c|c|c}
\hline & XVIII & XIX & XX & XX & TOTAL \\
\hline \multirow{2}{*}{ Plenos } & 97 & 24 & 112 & 81 & \multirow{2}{*}{314} \\
\cline { 2 - 5 } & $93,2 \%$ & $85,7 \%$ & $82,9 \%$ & $63,7 \%$ & \\
\cline { 2 - 5 } Perífrases & 7 & 4 & 23 & 46 & \multirow{2}{*}{80} \\
\cline { 2 - 5 } & $6,8 \%$ & $14,3 \%$ & $17,1 \%$ & $36,3 \%$ & \\
\hline \multirow{2}{*}{ TOTAL } & 104 & 28 & 135 & 127 & 394 \\
\hline
\end{tabular}

Tabela 2: Percentual das Instanciações de passar ao longo dos séculos

A análise dos dados demonstra o aumento de frequência nas construções de passar em perífrase ao longo dos séculos. No séculoXVIII a diferença é muito significativa, porque passar pleno se destaca de passar auxiliar, em razão de um uso mais concreto, mais físico, com sujeito [+agentivo][+humano], à medida que aumenta a frequência da perífrase, observa-se uma pequena diminuição em relação às construções com passar pleno. No século XXI pode-se considerar uma fixação dessa construção [(S) Vpassar + a + V2].

Interpretando o Gráfico 8, percebe-se a produtividade das construções perifrásticas, justificada em parte pela 
polissemia de passar, e em parte pelo caráter de passar ser um verbo leve, mais econômico em relação aos verbos começar, principiar e iniciar. Seu uso é facilmente acessado dentro do esquema [(S) V1 + a + V2], tornando coerente este aumento no século XXI. De acordo com Heine (2002), o estágio inicial está mais condizente com as construções dos séculos XVIII e XIX, em relação à mudança das construções com passar. O contexto ponte, também chamado de contexto de transição, está favorável no século $X X$, com o aumento gradativo das construções. No século XXI, há uma expansão desses usos, refletindo melhor o contexto de mudança, seguido da convencionalização da construção.

Nas análises anteriores, verificou-se que o tempo verbal que mais se adéqua nesse padrão construcional é o pretérito perfeito e o sujeito experienciador está mais vinculado a essa construção. As construções com passar lexical são mais concretas, bem representativas quando observamos o caráter polissêmico do verbo. Como já destacamos, o esquema de movimento está presente em todos os casos, para Heine (1993), o movimento assemelha-se a um processo básico da experiência humana. Defendemos a ideia de que mesmo quando o sujeito é estático, o verbo mantém em outro nível a ideia base de movimento, principalmente em relação ao tempo. Vejamos: 
(13) "Recebi mais uma carta tua a do dia 28 que muito me alegrou a Ismenia foi buscar de manha cedo por que eu tinha certeza que tinha carta tua eu fiquei muito contente de saber que você almocou em minha casa no Domingo e que foste a missa na Penha com o Zezinho e que foste na Quinta da Boavista com Antoninho e o Dalves e foste ao cinema que dizer que passaste um Domingo bem graças a Deus, eu você já sabes como eu passei muito resfriada e sozinha a qui feis um Domingo muito frio e choveu um pouquinho...". (PHPB)

A construção apresentada no exemplo (13) é considerada predicativa, pois denota um estado momentâneo do sujeito e o verbo passar pode ser substituído por verbos de ligação mais prototípicos como estar e ficar. Porém o semantema de passar é diferente, ainda que analisado como verbo de ligação, ele guarda a ideia base de movimento temporal em sua essência, como se segue: “... eu passei (por um determinado tempo) muito resfriada...".

Lakoff e Johnson (2002) chamam a atenção para o fato de muitos acharem que a metáfora é um recurso linguístico composto por características poéticas, esta caracterização não é obrigatória. Nesse sentido, a metáfora tem base em experiências humanas, além da linguagem, o pensamento e a ação também a envolvem. Para Lakoff, os mapeamentos metafóricos são regidos pelo Princípio da Invariância, de sorte que tais mapeamentos preservam a topologia cognitiva, correspondente à estrutura do esquema imagético, do domínio fonte de modo consistente com a estrutura 
inerente do domínio alvo. Com relação à noção de tempo, destacamos que "tempo é espaço" (A metáfora conceptual que motiva esta metáfora linguística é TEMPO É UM OBJETO EM MOVIMENTO): no exemplo (13), na construção "passei muito resfriada" está inferida uma relação forte entre o espaço e o tempo, no qual o sujeito esteve resfriado. Há um percurso metafórico percorrido nesse período, em que se esteve doente. Para Croft \& Cruse (2004, p. 194), “a metáfora é o resultado de um processo especial para se chegar ou construir um significado".

Trazendo os dados elencados e analisados dentro dos subesquemas de movimento para a visão construcional, nos moldes de Traugott (2012), inferimos que a mudança de uma construção lexical para uma construção perifrástica é gradual, micropasso por micropasso, a construcionalização pode incorporar noções tanto de gradualidade (diacrônica) como de gradiência (o resultado sincrônico da gradualidade). A mudança começa com microinovações no nível do token (construto), entretanto só pode ser considerada mudança quando a inovação se espalha para outros falantes e é convencionalizada como microconstrução.

\section{UMA REDE CONSTRUCIONAL}

Diante do exposto nas análises, pôde-se estabelecer uma rede construcional para as construções com o verbo 
passar, nucleada pela construção plena. Utilizamos o termo microconstrução, para representar os types empiricamente comprovados nas análises.

Nessa rede construcional partimos do verbo de movimento, que faz parte de um esquema mais abstrato e mais geral. O verbo passar faz parte desse esquema de verbo de movimento. As construções nucleadas por passar pleno, em um processo natural de expansão, vão ampliando seus types e consequentemente seus tokens pelo uso de seus constructos. Nesse sentido, pela análise dos dados, através dos subesquemas estabelecidos, acompanhamos as mudanças ocorridas nos movimentos do verbo passar. Assim comprovamos os movimentos físicos, acompanhando as relações do Sujeito com o Ponto de Referência. Analisamos os movimentos não físicos do Sujeito, como os movimentos psicológicos e os movimentos no tempo, em um sentido mais abstrato desse movimento. Verificamos em nossos dados o verbo passar em uso mais funcional, como verbo de ligação, como verbo suporte, evidenciando um sujeito experienciador e um movimento ligado ao percurso no tempo. As análises demonstraram que o verbo passar como auxiliar sofre o processo de gramaticalização, deixando de selecionar argumentos e funcionando como marcador de aspecto inceptivo, expressando a mudança de sua 
construção. Para Machado Vieira (2005), "alguns predicadores complexos, ao assumirem certas propriedades semânticas e morfossintáticas, se cristalizam e passam a integrar o inventário lexical da língua portuguesa". O esquema a seguir não fecha as movimentações do verbo passar, o objetivo é apresentar o resultado dos dados analisados e interpretados. Destacamos algumas microconstruções ilustrativas e em seguida o esquema geral das construções com passar.

\begin{tabular}{|c|c|c|c|}
\hline \multicolumn{4}{|c|}{ Microconstruções } \\
\hline Subesquema 1 & Subesquema 2 & Subesquema 3 & Subesquema - perífrase \\
\hline $\begin{array}{l}\text { “... eu passei na passa- } \\
\text { gem..." } \\
\text { “... eles passaram por } \\
\text { mim...” } \\
\text { “... uma menininha } \\
\text { passava lá...” }\end{array}$ & $\begin{array}{l}\text { “... eu passo o vídeo...” } \\
\text { “... passa o sabão...” } \\
\text { “... passa um xampu...” }\end{array}$ & $\begin{array}{l}\text { “... passava de novo o } \\
\text { lápis por cima..." } \\
\text { “... ela passava uma } \\
\text { imagem pra mim..." } \\
\text { “... e já passou a pala- } \\
\text { vra ao entrevistado...” }\end{array}$ & $\begin{array}{l}\text { “... aí ele passou a } \\
\text { frequentar a minha } \\
\text { casa...” } \\
\text { “... então ela passou a } \\
\text { ter medo,..." } \\
\text { “... nós passamos a con- } \\
\text { versar num dia qual- } \\
\text { quer..." }\end{array}$ \\
\hline
\end{tabular}

Quadro 9: Microconstruções de passar. 


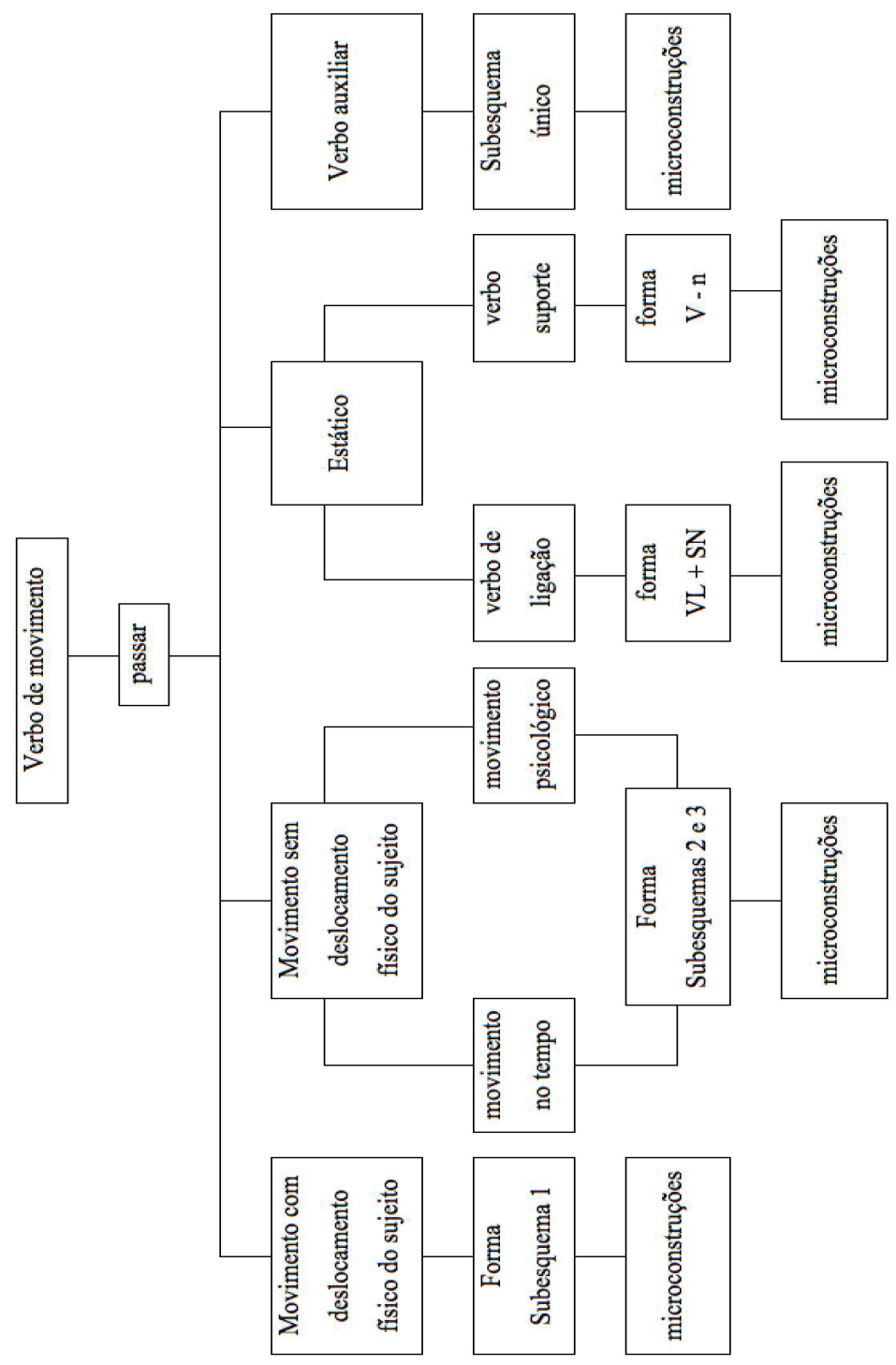

Figura 1: Esquema Geral para as construções com passar. 


\section{FECHAMENTO COM CROFT (2001)}

A partir dos tokens das microconstruções analisadas em nossos corpora, chegamos aos resultados que se seguem, principalmente, em relação ao deslizamento de passar pleno para passar auxiliar, com base em Croft (2001):

\section{Quanto à forma:}

a. Propriedades sintáticas: em nossos dados o verbo passar forma construções plenas e perifrásticas. A ordem sintática que prevalece é [S V Obl]. Como verbo pleno, exerce a função de predicador e seleciona seus argumentos. Como verbo auxiliar, perde a capacidade de predicar e carrega as categorias de tempo e aspecto. As construções plenas podem selecionar até quatro argumentos, em processo de expansão sintática.

b. Propriedades morfológicas: passar em construções perifrásticas perde traços de verbo pleno, vindo sempre associado a outro verbo chamado principal, normalmente, como apontam os dados, no infinitivo ou gerúndio. Há restrição no uso da preposição, cabendo nessa configuração somente a preposição "a", que indica direção. Passa a formar com o verbo predicador uma só categoria gramatical.

c. Propriedades fonológicas: uma constatação em nossa análise é a propriedade de passar se alinhar perfeitamente 
com construções preposicionadas, esse caso se deve ao fato de passar ser um verbo genuinamente de movimento, ligando-se a preposições mais gramaticalizadas, constituindo um grupo de força. Quanto mais entrincheirada é a construção mais força tem no meio em que é produtiva. Há dois casos no corpus D\&G, nos quais o grupo de força é maior pela ausência da preposição "a": "... passa achar..." e "... passa andando..." Fonologicamente analisando, o fato do auxiliar terminar com "a" e o principal iniciar com "a", pode ser representativo de uma crase. Mas há poucos dados para que isso seja taxativo.

\section{Quanto ao sentido:}

a. Propriedades semânticas: como verbo auxiliar, passar sofre uma mudança semântica, passando a marcar aspecto inceptivo. O sistema de transitividade é a base oracional da organização semântica da experiência, nesse sentido, o verbo passar pode selecionar argumentos, tendo expressiva produtividade como verbo transitivo predicador. As construções com passar predicador estão ligadas à rede temática que compõem seus argumentos e nas construções com passar auxiliar este não mais seleciona argumentos, mas sofre as flexões de tempo, número e pessoa.

b. Propriedades pragmáticas: pelo processo de analogia, as construções com passar auxiliar, por meio de reprodução 
de padrões já existentes em uma rede construcional e pelos slots ali existentes vai aumentando sua produtividade e consequentemente sua esquematicidade. As metáforas conceptuais, produzidas pelos falantes/ouvintes são responsáveis em parte por essa recategorização de verbo pleno para verbo auxiliar, ocorrendo a mudança funcional desse verbo e a fixação da nova função.

c. Propriedades discursivo-funcionais: a consideração do contexto dos casos analisados é fundamental, conforme se pode depreender do gráfico 8: "Instanciações de passar ao longo dos séculos", há predominância de construções com passar lexical no século XVIII num percentual de 93,2\%, em relação às construções perifrásticas (6,8\%), na análise das ocorrências em sequências narrativas de Cartas particulares. O gênero foi selecionado em virtude de representar, em nosso entendimento, interessante meio de comunicação pessoal, e comum nesse século. No século XIX ocorre uma expansão da construção perifrástica para contextos em que a unidade começa a ser mais usada. Ainda analisando o gráfico 8, o século XX denota o espaço ideal para o aumento mais significativo para as construções perifrásticas, é o contexto que apresenta o real gatilho do processo de gramaticalização. No século XXI, distinguimos o contexto de isolamento, pois apresenta a consolidação do processo de gramaticalização. 
Embora Diewald defenda o desaparecimento do estágio dois com o desenvolvimento do contexto de isolamento. Isso não ocorre com o verbo passar cujas formas plena e perifrástica convivem num sistema de Camadas, conforme Hopper (1991).

\section{CONSIDERAÇÕES FINAIS}

Ao finalizar esse artigo, que apresenta um recorte de nossa tese, procuramos demonstrar as mudanças ocorridas com o verbo passar, conforme análise de dados e assumimos que deslocamos nossa visão de gramaticalização do item para a gramaticalização da construção, entendendo ser esse fato um importante fator na análise de mudança linguística. Conforme Rosário (2015, p. 45), “assim, atualmente é mais acertado considerarmos a gramaticalização um fenômeno sintático, discursivo-pragmático, que deve ser estudado do ponto de vista de modelos fluidos de língua (ver TRAUGOTT, HEINE, 1991, p.1)". Para Rosário (op. cit), "essa perspectiva está no bojo do que se denomina "gramaticalização de construções".

Constatamos que o deslizamento do verbo passar em sentido pleno, lexical, do padrão transitivo, que subcategoriza diferentes preposições, ao assumir a posição de auxiliar, vai subcategorizar apenas a preposição a em suas construções, fato verificável nos resultados obtidos. Nesse sentido, pode- 
se concluir que o valor semântico associado à preposição a é de movimento, sendo assim, esta é a construção que o usuário da língua usa. A seguir, apresentamos a tabela do emprego da preposição a nas construções perifrásticas:

\begin{tabular}{|c|c|c|c|c|c|}
\hline $\begin{array}{c}\text { Tipo de } \\
\text { construção }\end{array}$ & $\begin{array}{c}\text { Vpassar+a+V2 } \\
76\end{array}$ & $\begin{array}{c}\text { Vpassar+V2 } \\
2\end{array}$ & $\begin{array}{c}\text { V1+Vp+a+V3 } \\
1\end{array}$ & $\begin{array}{c}\text { Vpassar+Vger } \\
1\end{array}$ & $\begin{array}{c}\text { Total } \\
80\end{array}$ \\
\hline Prep.. "a" & 76 & - & 1 & - & 77 \\
\hline Percentual & 95,0 & 2,5 & 1,25 & 1,25 & 100 \\
\hline
\end{tabular}

Tabela 3: Emprego da preposição a

Para Martelotta (2010), é o caráter eminentemente contextual da noção de construção que é fundamental para que se dê conta dos movimentos de mudança que caracterizam os elementos linguísticos.

Pode-se dizer que esse artigo contribui com as investigações no campo da gramaticalização de construções verbais que apresentam, ao longo do tempo e pelo aumento de frequência (BYBEE, 2010), a mudança linguística de suas construções. Destacando, ainda, que, de acordo com Traugott (2012), mudanças construcionais podem preceder ou acompanhar construcionalização.

\section{REFERÊNCIAS}

ARENA, Ana Beatriz (2015). Construcionalização do conector DAÍ QUE em perspectiva funcional centrada no uso. 186f. Tese (Doutorado em Estudos de Linguagem), Universidade Federal Fluminense, Rio de Janeiro. 
BYBEE, Joan (2007). Frequency of Use and the Organization of Language. Oxford: Oxford University Press. (2015). Language change. Cambridge: Cambridge University Press. (2010). Language, Usage and Cognition. Cambridge: Cambridge University Press.

(2008). "Mechanisms of change in Grammaticalization: the role of Frequency". In: JOSEPH, Brian D.; JANDA, Richard D. (Edits.). The Handbook of Historical Linguistcs. Blackwell Publishing.

CANÇADO, Marcia (2005). "Argumentos: complementos e adjuntos". In OFICINA DE SEMÂNTICA, maio. Faculdade de Letras/UFMG, Belo Horizonte. Manuscrito. In http://www.letras.ufmg.br/

CASTILHO, Ataliba T. de (2002). Aspecto verbal no Português falado. In: ABAURRE, M.B.; RODRIGUES A.C.S. (Orgs.). Gramática do Português Falado. Novos estudos descritivos. Campinas: Ed. Unicamp, v.8, p.83 116.

(2014). Nova Gramática do Português Brasileiro. São Paulo: Contexto.

CROFT, William (2001). Radical Construction Grammar. Syntactic Theory in Typological Perspective. Oxford Linguistics. Oxford Univerity Press.

; CRUSE, Alan (2004). Cognitive linguistics. 2.ed. New York: Cabridge University Press.

CUNHA, Maria Angélica Furtado da; CÉSAR, Alan Marinho (2014). Enquadramentos Semânticos para Verbos de Movimento Transitivos Diretos. In https://academia.edu. Acesso em 10. Jan.2018.

DIAS, Nilza Barrozo (2013). Categorias de léxico: distinção entre categoria gramatical e lexical. Material de estudo. UFF.

DIEWALD, Gabriele (2006). "Context types in grammaticalization as constructions". Constructions. SV 1-9. In www.constructions-online.de. Acesso em 18.Dez.2018

GOLDBERG, Adele Eva (1995). Constructions: A construction Grammar Approach to Argument Structure. Chicago: The University of Chicago Press. 
(2003). Constructions: A new theoretical approach to language. Trends in Cognitive Sciences. Linguistics Department, University of Illinois, Urbana, IL 61801-0168, USA. 7(5), maio, p.219-224.

(2006). Constructions at work: The nature of generalization in language. Oxford: Oxford University Press.

HALLIDAY, Michael Alexander Kirkwood (1994). An introduction to functional grammar. London: Edward Arnold.

HEINE, Bernd (1993). Auxiliaries. Cognitive force and grammaticalization. Oxford: Oxford University Press.

(2008). "Grammaticalization". In: JOSEPH, Brian D.; JANDA, Richard D. (Edits.). The Handbook of Historical Linguistcs. Blackwell Publishing, p.575-601.

(2002). "On the role of context in grammaticalization". In: WISCHER, I; DIEWALD, G. (Edits.). New reflections on grammaticalization. Philadelphia, PA: John Benjamins Publishing Company.

; CLAUDI, Ulrike; HÜNNEMEYER, Friederike (1991). Gramaticalization: a conceptual framework. Chicago: The University of Chicago Press.

; KUTEVA, Tania (2007). Language contact and grammatical change. Cambridge: Cambridge University Press. (2007). The genesis of grammar: a reconstruction. Oxford: Oxford University Press.

HOPPER, Paul J. (1991). "On some principles of grammaticalization". In: TRAUGOTT, E. C.; HEINE, Bernd (Edits.). Approaches to grammaticalization. Focus on theoretical and methodological issues, vol I. Amsterdam/ Philadelphia: John Benjamins Publishing Company, p.17-36.

; THOMPSON, Sandra (1980). "A. Transitivity in grammar and discourse". Language, 56(2), junho, 251-299.

(2001). "Transitivity, clause structure, and argument structure: evidence from conversation". In: BYBEE, Joan; HOPPER, Paul J. (Edits.). Frequency and the emergency of linguistic structure. Amsterdam: John Benjamins. 
; TRAUGOTT, Elizabeth Closs (1993). Grammaticalization. Cambridge: Cambridge University Press.

JORDÃO, Geisa Maria Jayme (2011). "Um Estudo de Gradiência com o Verbo Passar". Revista Caligrama. Belo Horizonte, 16(2), 229-243.

MACHADO VIEIRA, Márcia dos Santos (2005). "O caráter multifuncional de certos verbos do Português". XIV Congreso Internacional de la Asociación de Lingüística y Filología de América Latina (ALFAL). Monterrey: ALFAL, v.1, p.176-185. In http://www.mundoalfal.org/cdcongreso/cd/historia portugues/vieira.swf. Acesso em 10.Jan.2018.

MARTELOTTA, Mário Eduardo (2010). "Categorias cognitivas e unidirecionalidade". In: LIMA-HERNANDES, Maria Célia et al (Org.). Gramaticalização em Perspectiva. Cognição, Textualidade e Ensino. São Paulo: Paulistana.

(2011). Mudança linguística: uma abordagem baseada no uso.

São Paulo: Cortez.

NEVES, Maria Helena de Moura (2000). Gramática de Usos do Português. São Paulo. Editora UNESP.

OLIVEIRA, Mariangela Rios de; ROSÁRIO, Ivo da Costa do. (Org.) (2015). Linguística Centrada no Uso. Teoria e método. Rio de Janeiro: Editora Lamparina.

ROSÁRIO, Ivo da Costa do. OLIVEIRA, Mariangela Rios de (2016). Funcionalismo e abordagem construcional da Gramática. São Paulo: Alfa, p.233-259

TRAUGOTT, Elizabeth Closs (2008). "Constructions in grammaticalization". In: JOSEPH, Brian D.; JANDA, Richard D. (Edits.). The Handbook of Historical Linguistcs. Blackwell Publishing, p.624-648.

(2012). Na direção de um conjunto coerente de Construcionalização Gramatical. Projeto para um volume de gramática de construção histórica. March.

; TROUSDALE, Graeme (2013). Constructionalization and constructional changes. Oxford: Oxford University Press. 
TRAVAGLIA, Luiz Carlos (2006). O Aspecto Verbal no Português: a categoria e sua expressão. 4.ed. Uberlândia: EDUFU.

(2010). "Uma gramaticalização em cadeia para indicação de aspectos". In: VITRAL, Lorenzo; COELHO, Sueli (Orgs.). Estudos de gramaticalização em Português: metodologias e aplicações. Campinas: Mercado de Letras, p.105-137

TROUSDALE, Graeme (2014). "On the relationship between grammaticalization and constructionalization". Folia Linguística, 48(2).

WIEDEMER, Marcos Luiz (2014). "Para uma visão conceptual das preposições que complementam verbos de movimento no português brasileiro". Revista Veredas, 102-122.

(2014). "O desenvolvimento das preposições de complemento de verbos de movimento: do latim ao português". Sociodialeto. 4(22), 365386. Edição. Especial em homenagem a Fernando Tarallo.

Geisa Maria Jayme Jordão é Doutora em Estudos de Linguagem. Universidade Federal Fluminense - Niterói. Publicou na Revista Caligrama o artigo" UM ESTUDO DE GRADIÊNCIA COM O VERBO PASSAR." Participante do Grupo de Pesquisa PORUS - Núcleo de Estudos Linguísticos do português em uso (UFF). Atua como Professora de Português da Rede Municipal do RJ. 